\title{
ROLE OF BIOMARKERS AND IMMUNO COMPLEMENTS C3 AND C4 LEVELS IN CHRONIC LIVER DISEASES IN EGYPTIAN PATIENTS
}

\author{
Abdel Wahab, Hanan, M. ${ }^{(1)}$; El-Kirsh, Amal, A. ${ }^{(1)}$; Ibrahim, M. H. ${ }^{(2)}$ \\ and Madkour, Amany, A. A. ${ }^{(3)}$ \\ 1) Faculty of Women for Arts, Science and Education, Ain Shams University. \\ 2) Military Medical Academy. 3) Armed Forces Medical research \\ Laboratories and Blood Bank.
}

\begin{abstract}
Majority of the population of Egypt has a heavy burden of liver diseases, mostly due to chronic infection with hepatitis $\mathrm{C}$ and $\mathrm{B}$ viruses (HCV and HBV) and Bilharzias that is considered as important environmental risk factor, which can go unnoticed until decades after infection, when liver damage becomes evident. This study is conducted to aid the Egyptian ministry of health to continue in the program of controlling $\mathrm{HCV}$ and Schistosomiasis to avoid patients suffering from failed treatments initiatives as in the past in treatment of schistosomasis by further investigations for diseases and its follow up. The study population included patients attending the Armed Forces Medical research Laboratories and Blood Bank.

Individuals under investigation were divided into four groups comprising 30 individuals each. Group (1): included normal healthy individuals, group (2): included patients with chronic HCV, group (3): included patients with chronic HCV and group (4): included patients with Bilharzias (BILZ) infected by Schistosomiasismansoni .All patients (HCV, HBV and BILZ) groups were characterized by increase in all biochemical markers of liver function tests (AST, ALT and GGT) and reduction in albumin level in their sera as compared to the normal control group.

The results also illustrated that in $\mathrm{HCV}$ and HBVgroups, there were significant reduction in serum levels of complement system $\mathrm{C} 3$ and $\mathrm{C} 4$, these effects were associated with significant increase in AFP level compared to normal control group. But HCV RNA viral load as measured by quantitative
\end{abstract}


PCR showed no statistically significant correlation with AST, ALT, GGT , AFP , C3, C4 and albumin in patients suffering from HCV.

Key words: HCV, HBV, Complements 3 and 4, Bilharziasis, AFP.

\section{INTRODUCTION}

Schistosomiasis is a significant environmental health problem in more than 70 countries distributed between Africa, Asia and South America, with an infection rate of one in 30 individuals. Data on Schistosomiasis, hepatitis B virus (HBV) and hepatitis $\mathrm{C}$ virus (HCV) co-infection are scarce. However, there is a high prevalence in countries where schistosomiasis is endemic (Gasim et al., 2015).

It is known that the major cause of death is primarily associated with cirrhosis in the liver as well as other conditions including liver failure, hematemesis from esophageal varices, hepatic encephalopathy and hepatocellular carcinoma. It was regarded that $\mathrm{HCV}$ may complicate the course of schistosomiasis and vice versa with a perhaps synergistic effect (Ruane et al., 2015).

Waterborne diseases have been estimated to cause more than two million deaths and four billion cases of diarrhea annually. Waterborne pathogenic organisms include bacteria, protozoa and viruses. Heavy metal contamination of water is also a potential threat to human health (El-Kowrany et al., 2015). Domestic activities such as washing clothes and fetching water in infected water expose women and children to infection. Recreational activities like swimming and poor hygiene also make children vulnerable to Schistosomiasis (WHO, 2017).

According to the World Health Organization there are $130-150$ million people chronically infected with the hepatitis $\mathrm{C}$ virus (HCV), corresponding to 2$2.5 \%$ of the world's total population. There are considerable regional differences. The prevalence in Egypt is $>10 \%$ (WHO 2015). Approximately 20-30\% of 
chronically infected individuals develop cirrhosis over a 20 to 30 year period of time (Vogel et al., 2009).

Alfa fetoprotein (AFP) has been regarded as the most useful serum protein thus far for patients at risk for hepatocellular carcinoma (HCC) (Zhou et al., 2006). However, its sensitivity for detecting HCC ranges between $25 \%$ - $60 \%$ and its specificity is also low because serum AFP can also be detected in patients with cirrhosis (11\%-47\%) and chronic hepatitis (15\%-58\%) (EL-Serag et al., 2008). An increase in the serum concentration of AFP is primarily used as a tumor marker for HCC evaluation and liver cirrhosis (Li et al.,2001).

The complement system is also involved in the pathogenesis of a variety of liver disorders, including viral hepatitis, liver injury and repair, fibrosis, alcoholic liver disease, and liver ischemic/reperfusion injury (Qin and Gao, 2006). Complement components contribute to clearance of virus infections both directly and indirectly, contributing to lysis of enveloped virions (Gerencer et al., 1998) and virus infected cells, through the action of the C5-C9 membrane attack complex (Terajima et al., 2011).

Direct anti-viral properties of some innate immune proteins, as well as indirect evidence inferred by the modulation of innate immune activity by virus-encoded proteins, however, suppression of humoral innate immunity by $\mathrm{HCV}$, and the role of these proteins in HCV pathogenesis are also considered. (Tarr et al.,2012).

The aim of the present study was to investigate the impact of liver biomarkers, AFP and complements $\mathrm{C} 3$ and $\mathrm{C} 4$ as immune biomarkers in sera of individuals suffering from these three diseases for the hope of early screening for population who are at risk for developing liver. 
J. Environ. Sci.

Institute of Environmental Studies and Research - Ain Shams University

\section{SUBJECTS AND METHODS}

Case-control study carried out on 120 male individuals was divided into the following groups: Group (1): Normal control group, including 30 clinically healthy individuals, they were healthy volunteers.

Group (2): Hepatitis C virus group (HCV), including 30 patients infected with hepatitis $\mathrm{C}$ virus. They had HCV RNA in their sera as evidenced by polymerase chain reaction (PCR) (QIAsymphony DSP Virus/Pathogen kit, sarstedt AG and Co.) carried out on QIA symphony sp.

Group (3): Hepatitis B virus group (HBV), including 30 patients infected with hepatitis B virus. HBV patients were diagnosed by positive hepatitis B surface antigen using qualitative detection by the chemiluminescentmicro particles immunoassay (CMIA) technology according to Locarnini (1998) using the instructions provided by Abbot Ireland diagnostic.

Group (4): Bilharziasis or schistosomiasis group, including 30 patients suffer from Schistosoma mansoni infestation. Bilharziasis patients were diagnosed by positive Schistosoma mansoni antibodies using the indirect hemagglutination test (IHA) according to Felidmeier and Zwingenberger (1988) using the kit provided by the Siemens Healthcare Diagnostics, Germany.

There was no significant difference between ages of normal control and patient groups, as their mean ages were as follows: group (1): (48.9 \pm 0.69$)$; group

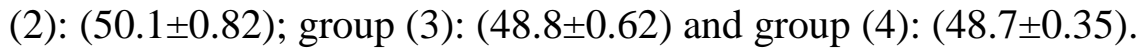

Venous blood samples were withdrawn from patients and healthy persons. The samples were collected in dry sterile $5 \mathrm{ml}$ tubes and were allowed to clot at $37^{\circ} \mathrm{C}$ for 15 minutes and centrifuged at $4000 \mathrm{rpm}$ for 10 minutes, then, sera were 
separated. Sera of subjects of the controls and patients were subjected to quantitative determination of the following biochemical parameters according to kits instruction manual.

1. Routine laboratory investigations as: some liver function tests including AST, ALT, GGT and albumin were performed as follows: Alanine and aspartate aminotransferases and gamma glutamyltransferases were measured according to Bakker and Müke ( 2007) and serum albumin according to Buritis et al. (2006) using the kits supplied by Roche Diagnostics /LTD, USA on Hitachi modular.

2. Alfa fetoprotein was determined by using a chemiluminescentmicro particles immunoassay (CMIA) technology according to Baumgarten and Robinson (1988) using instructions provided by Abbott Ireland Diagnostics on vitrous 5600 .

3. Serum C3 and C4 complement concentrations were estimated by immunonephelometry according to Thomas (1998) using commercially available kit provided by Siemens Healthcare Diagnostics, Germany on BN prospect.

\section{Statistical analysis:}

Results were expressed as mean \pm SE. One way analysis of variance (ANOVA) followed by post hoc least significant difference analysis (LSD) were performed using the statistical package for social science (SPSS) version 16 to compare different groups. Pearson's correlation coefficient (r) was used to find the degree of correlation between some of biochemical parameters estimated in serum of $\mathrm{HCV}$ patients .Differences were considered significance when $\mathrm{P} \leq 0.05$. Percentage of difference representing the percent of variation with respect to normal control. 
J. Environ. Sci.

Institute of Environmental Studies and Research - Ain Shams University

\section{RESULTS}

As illustrated in table (1), transfereases AST and ALT activities were significantly elevated in the serum of patients groups as compared to normal control (G1). The increase of AST in HCV group was more evident and amounted to $160.93 \%$ of the normal control group. However, the mean \pm SE recorded (38.85 $\pm 2.27 \mathrm{U} / \mathrm{L}$ for AST) and (33.54 $\pm 1.92 \mathrm{U} / \mathrm{L}$ for ALT) in patients with bilharzias, does not exceed the accepted upper level of normal reference range which is up to 40U/L.

It was found that HCV caused significant increase and decrease in the AST activity and albumin concentration respectively as compared to $\mathrm{HBV}$ and bilharzias patients. Furthermore, HBV patients had higher value of ALT than bilharzias patients (51.78 \pm 2 VS $33.54 \pm 1.92 \mathrm{U} / \mathrm{L})$.

The results also indicated that there were significant decrease of serum albumin and increase of serum GGT activity in HCV (G2) and bilharzias (G4) as compared to normal control .Albumin concentration and GGT activity estimated in serum of HBV patients (G3) were found to be within normal reference range (3.97$4.94 \mathrm{~g} / \mathrm{dl})$ and $(8-61 \mathrm{U} / \mathrm{L})$ respectively with mean values $\pm \mathrm{SE}(4.40 \pm 0.13 \mathrm{~g} / \mathrm{dl})$ and $(40.48 \pm 2.07 \mathrm{U} / \mathrm{L})$ respectively.

It was found that when HBV compared to bilharzias group, there was a significant increase in the activities of serum AST and ALT and serum albumin concentration. Furthermore, the mean value of ALT activity which was recorded in patients with $\mathrm{HCV}$ tended to have non-significant decrease as compared to $\mathrm{HBV}$ patients and significant increase as compared to patients with bilharzias. 
Table (1): Activites of serum aspartate and alanine aminotransferases (AST and ALT), gamma glutamyl transferase (GGT) and concentration of serum albumin in different experimental groups

\begin{tabular}{|c|c|c|c|c|}
\hline $\begin{array}{c}\text { Parameters } \\
\text { group }\end{array}$ & $\begin{array}{c}\text { AST } \\
(\mathbf{U} / \mathbf{L})\end{array}$ & $\begin{array}{c}\text { ALT } \\
(\mathbf{U} / \mathbf{L})\end{array}$ & $\begin{array}{c}\text { GGT } \\
(\mathbf{U} / \mathbf{L})\end{array}$ & $\begin{array}{c}\text { Albumin } \\
(\mathbf{g} / \mathbf{d l})\end{array}$ \\
\hline $\begin{array}{c}\text { G1(normal control) } \\
\text { Mean } \pm \text { SE }\end{array}$ & $25.83 \pm 1.00$ & $25.90 \pm 1.32$ & $35.90 \pm 1.58$ & $4.48 \pm 0.1$ \\
\hline $\begin{array}{c}\text { G2(HCV) } \\
\text { Mean } \pm \text { SE }\end{array}$ & $\begin{array}{c}67.40 \pm 4.27^{\mathrm{a}} \\
160.93 \%\end{array}$ & $\begin{array}{c}48.71 \pm 2.47^{\mathrm{a}} \\
88.06 \%\end{array}$ & $\begin{array}{c}72.25 \pm 6.98^{\mathrm{a}} \\
101.3 \%\end{array}$ & $\begin{array}{c}3.29 \pm 0.11^{\mathrm{a}} \\
-26.56 \%\end{array}$ \\
\hline $\begin{array}{c}\text { Percentage of change } \\
\text { Mean } \pm \text { SE }\end{array}$ & $\begin{array}{c}55.96 \pm 1.73^{\mathrm{ab}} \\
116.6 \%\end{array}$ & $\begin{array}{c}51.78 \pm 2.00^{\mathrm{a}} \\
99.92 \%\end{array}$ & $\begin{array}{c}40.48 \pm 2.07^{\mathrm{b}} \\
12.76 \%\end{array}$ & $\begin{array}{c}4.40 \pm 0.13^{\mathrm{b}} \\
-1.78 \%\end{array}$ \\
\hline $\begin{array}{c}\text { Gercentage of change } \\
\text { Mean } \pm \text { SE }\end{array}$ & $\begin{array}{c}38.85 \pm 2.27^{\mathrm{abc}} \\
50.4 \%\end{array}$ & $\begin{array}{c}33.54 \pm 1.92^{\mathrm{abc}} \\
29.49 \%\end{array}$ & $\begin{array}{c}62.93 \pm 3.86^{\mathrm{ac}} \\
75.29 \%\end{array}$ & $\begin{array}{c}3.90 \pm 0.17^{\mathrm{abc}} \\
-12.95 \%\end{array}$ \\
\hline Percentage of change & \multicolumn{3}{|c|}{} \\
\hline
\end{tabular}

Values are presented as means \pm SE

Letters $\mathrm{a}, \mathrm{b}$ and $\mathrm{c}$ represent statistical differences with groups 1,2 and 3 at $\mathrm{P}<0.05$ respectively.

Group1: normal control, Group 2: Hepatitis C Virus (HCV), Group 3: Hepatitis B Virus (HBV) and Group 4: Bilharzias (BILZ).

The normal ranges are up to $41 \mathrm{U} / \mathrm{L}$, up to $40 \mathrm{U} / \mathrm{L}, 8-61 \mathrm{U} / \mathrm{L}$ and 3.97-4.94 g/dl for ALT, AST, GGT and albumin respectively.

Percent of change for AST, ALT, GGT and albumin from normal control (group1) respectively.

Table (2) shows that the concentration of alfa fetoprotein was significantly increased in the sera of all disease groups compared to control, and the increase was evident in the HCV group reading to $883.88 \%$ of the normal control with the knowledge that the mean \pm SE of AFP $(6.09 \pm 0.67$ $\mathrm{ng} / \mathrm{ml}$ ) estimated in G4 was near the upper normal reference range (0-7 ng/ml). AFP was significantly higher in $\mathrm{HCV}$ patients and HBV patients compared with bilharzias group and also in HCV compared with HBV group. 
In this work, the percentage decreases in the levels of $\mathrm{C} 3$ and $\mathrm{C} 4$ complements were $-52.46 \%$ and $-57.89 \%$ respectively in the serum of HCV patients compared to control (G1). The mean $\pm \mathrm{SE}$ for $\mathrm{C} 3$ and $\mathrm{C} 4$ measured in the sera of HBV and bilharzias patients showed normal reference range. The sera from patients infected with HCV and HBV displayed significantly lower C3 complement then sera from bilharzias patients. Also levels are decreased in $\mathrm{HCV}$ patients compared with HBV patients.

Table (2): Concentration of serum tumor marker, alpha fetoprotein (AFP) and levels of immunoassay complements 3 and 4 (C3 and C4) in different experimental groups

\begin{tabular}{|c|c|c|c|}
\hline Parameters Groups & $\begin{array}{c}\text { AFP } \\
(\mathbf{n g} / \mathbf{m l})\end{array}$ & $\begin{array}{c}\text { C3 } \\
(\mathbf{m g} / \mathbf{d l})\end{array}$ & $\begin{array}{c}\text { C4 } \\
(\mathbf{m g} / \mathbf{d l})\end{array}$ \\
\hline \hline $\begin{array}{c}\text { G1(normal control) } \\
\text { Mean } \pm \text { SE }\end{array}$ & $2.42 \pm 0.19$ & $139.71 \pm 2.92$ & $20.33 \pm 1.11$ \\
\hline $\begin{array}{c}\text { G2(HCV) } \\
\text { Mean } \pm \text { SE }\end{array}$ & $\begin{array}{c}23.81 \pm 1.45^{\mathrm{a}} \\
883.88 \%\end{array}$ & $\begin{array}{c}66.41 \pm 3.61^{\mathrm{a}} \\
-52.46 \%\end{array}$ & $\begin{array}{c}8.56 \pm 0.57^{\mathrm{a}} \\
-57.89 \%\end{array}$ \\
\hline $\begin{array}{c}\text { Percentage of change } \\
\text { Mean } \pm \text { SE }\end{array}$ & $\begin{array}{c}18.53 \pm 0.92^{\mathrm{ab}} \\
665.7 \%\end{array}$ & $\begin{array}{c}101.94 \pm 3.14^{\mathrm{ab}} \\
-27.03 \%\end{array}$ & $\begin{array}{c}9.90 \pm 0.48^{\mathrm{a}} \\
-51.3 \%\end{array}$ \\
\hline $\begin{array}{c}\text { Percentage of change } \\
\text { G4 (BILZ) }\end{array}$ & $6.09 \pm 0.67^{\mathrm{abc}}$ & $\begin{array}{c}138.93 \pm 5.12^{\mathrm{bc}} \\
-0.56 \%\end{array}$ & $\begin{array}{c}27.14 \pm 1.48^{\mathrm{abc}} \\
33.5 \%\end{array}$ \\
$\begin{array}{c}\text { Mean } \pm \text { SE } \\
\text { Percentage of change }\end{array}$ & $210.3 \%$ & & \\
\hline
\end{tabular}

Values are presented as means \pm SE.

$>$ Letters $\mathrm{a}, \mathrm{b}$ and $\mathrm{c}$ represent statistical differences with groups 1,2 and 3 at $\mathrm{P}<0.05$ respectively.

> Group (1): Normal control, Group (2): Hepatitis C Virus (HCV), Group(3): Hepatitis B Virus (HBV) and Group (4): Bilharzias (BILZ).

$>$ The normal ranges are $0-7 \mathrm{ng} / \mathrm{ml}, 90-180 \mathrm{mg} / \mathrm{dl}$ and $10-40 \mathrm{mg} / \mathrm{dl}$ for AFP, C3\& C4 respectively.

Percent of change for AFP, $\mathrm{C} 3$ \& $\mathrm{C} 4$ from normal control (group 1) respectively. 
The current study revealed also that HCV RNA viral load as measured by quantitative PCR showed no statistically significant correlation with AST $(\mathrm{P}=0.762, \mathrm{r}=0.076) ; \operatorname{ALT}(\mathrm{P}=0.932, \mathrm{r}=0.253) ; \mathrm{GGT}(\mathrm{P}=0.793, \mathrm{r}=0.117)$; AFP $(\mathrm{P}=0.394, \mathrm{r}=0.072)$; $\mathrm{C} 3(\mathrm{P}=0.716, \mathrm{r}=0.122)$; $\mathrm{C} 4(\mathrm{P}=0.194, \mathrm{r}=$ $0.008)$ and albumin $(\mathrm{P}=-0.80, \mathrm{r}=0.0798)$ in patients suffering from hepatitis C virus (G2).

\section{DISSCUSSION}

From the current study at table (1), it was found that there is a significant increase in the activities of aminotransferases (AST and ALT) in the serum of patients with hepatitis $C(\mathrm{G} 2)$ and hepatitis B (G3) viruses. The awareness of hepatic intracellular enzymes that have leaked into the circulation was indicated by significant elevation of ALT and AST. These are the markers for hepatocellular damage (Ni et al., 2012).

In this study, the activity of aminotransferases (AST and ALT) of patients with bilharizias which were found to be $(33.54 \pm 1.92 \mathrm{U} / \mathrm{L}$ and 38.85 $\pm 2.27 \mathrm{U} / \mathrm{L}$ respectively) at the upper normal reference range but still significantly higher than normal control. This is accordance with Leite et al. (2013) who reported that the patients with hepatosplenic schistosomiasis showed abnormal liver function tests compared to the healthy controls with significantly increased levels of serum AST and ALT. Toda et al. (2015) reported that infection with $S$. mansoni may be a possible risk factor for $\mathrm{HCC}$ which is considered the fifth most common cause of cancer in the world.

The present study revealed that, there is no significant correlation at $(\mathrm{P}<0.05)$ when comparing PCR with either AST, ALT, GGT, C3, C4, AFP 
and albumin which were measured in the serum of patients suffering from HCV (G2). Abraham et al. (2009) showed that the viral load was independent of ALT level in HCV. Also, at the same time they observed no significant correlation between HCV RNA viral load and AST levels. The present data agreed with the results obtained by Noreldin et al. (2015) who found that high results of liver function tests may be indicator for the severity of liver damage in chronic HCV patients but also PCR should be done as some cases show normal results while their PCR was high.

Moreover, results in table (1) indicates that $\mathrm{HCV}, \mathrm{HBV}$ and bilharizias led to decrease in the concentration of serum albumin when compared to healthy people. In disease states, hypoalbuinaemia is secondary to decreased human serum albumin production or transcapillary leakage into the interstitial space. The previous study with Leite et al. (2013) demonstrated a lower concentration of albumin in serum patients with hepatosplenicschistosomiasis. However, Leckie et al. (2012) have shown that the function of human serum albumin is impaired in patients with cirrhosis.

In the present study data, and in relation to normal control, although, there are significant elevation in serum GGT activity, the non significant elevations was only in HBV patients. Previous studies identified GGT as a prognostic marker of fibrosis in chronic liver diseases (Iacobellis et al., 2005) and schistosomiasis (Souza et al., 2000). The current results were matched with results of Hui et al. (2005) who reported that, the chronic hepatitis which is caused by the hepatitis B and C viruses is associated with high GGT levels, 
which can be used as a noninvasive diagnostic marker and as a predictor of fibrosis.

It is obvious that $\mathrm{HCV}$ and $\mathrm{HBV}$ patients demonstrated pronounced elevation in the AFP concentration compared to bilharizias patients, table (2). Zakhary et al. (2011) revealed that benign liver diseases such as schistosomiasis, hepatitis and cirrhosis also showed elevated levels of the protein, but it was still significantly lower than that of HCC. Beside to the elevation of AFP in patients with $\mathrm{HCV}$ and $\mathrm{HBV}$ than bilharizias patients, ALT elevation was seen in the current study. In the same concern Li et al. (2017) suggested that, higher serum levels of AFP and ALT were risk factors associated with the development of $\mathrm{HCC}$, regular monitoring of these serum markers in hepatic cirrhosis patients is necessary.

However, when comparing patient groups with normal persons in the present study, it was found that patients with $\mathrm{HCV}$ showed significant reduction in serum $\mathrm{C} 3$ and $\mathrm{C} 4$. They reached $-54.46 \%$ and $-57.89 \%$ respectively as compared to normal control.

HBV significantly reduced $\mathrm{C} 3$ and $\mathrm{C} 4$ relative to normal control but still at low normal reference range. The complement $\mathrm{C} 4$ levels were observed to be increased in the bilharizias patients relative to normal control where the increase still within normal reference ranges $(10-40 \mathrm{ng} / \mathrm{dl})$. The complement system is one of the most important weapons of innate immunity and is involved in all infectious processes. It is not only a mechanism for direct protection against an invading pathogen but also interact with the adaptive immunity to optimize the pathogen-specific humoral and cellular defense cascade in the body (Speth et al., 2003). Lower complement levels were 
closely correlated with liver injury and impaired liver aggregation (Zhang, et al., 2016).

Castellanos et al. (2011) found that C3 and C4 complements decreased significantly in cirrhotic patients. They suggested that the reduction by alternative pathway can be the result of an increased consumption or a decreased production due to liver insufficiency. Furthermore, Pasha et al. (2017) reported that the levels of complements C3 and C4 in liver of cirrhotic patients were grossly decreased when compared with controls.

\section{CONCLUSION}

The measurement of serum albumin, immune complements (C3 and C4) and AFP may be used to increase the overall, diagnostic accuracy in hepatitis $\mathrm{C}$ and to less extent $\mathrm{B}$ viruses.

\section{REFERENCES}

Abraham, R.; Ramakrishna, B.; Balekuduru, A.; Daniel, H. D. J.; Abraham, P.; Eapen, C. E. \& Kurian, G. (2009): Clinicopathological features and genotype distribution in patients with hepatitis $\mathrm{C}$ virus chronic liver disease. Indian Gastroenterol; 28: 53-58.

Bakker, A. J. \& Mücke, M. (2007): Gammopathy interference in clinical chemistry assays mechanisms, detection and preventation: Clin. Chem. Lab. Med.; 45(9):1240-1243.

Baumgarten, A. \& Robinson, J. (1988): Prospective study of an inverse relationship between maternal glycosylated hemoglobin and serum alfa fetoprotein concentrations in pregnant women with diadetes. Am. J. Obstet Gynecol., 159(1):77-81. 
Buritis, C.A.; Ashwood, E. R. \& Bruns, D. E. (2006): Clinical Chemistry, Molecular Diagnostics, and Laboratory Medicine. In: Tietz textbook of clinical chemistry and molecular diagnostics, $4^{\text {th }}$ ed. St. Lcuis, Missouri, Elsevier Saunders; pp: 106-104.

Castellanos, M. I.; Seijas, O. R.; González, D.; Ronquillo, M.; Abreu, M. R. \& Ojeda, S. (2011): Immune alterations in liver cirrhosis: Its Relationship with Etiology, Child Pugh stage and malnutrition. J. Nutr. Disorders Ther.; 1: 1-8.

El-Kowrany, S. I.; El-Zamarany, E. A.; El-Nouby, K. A.; El-Mehy, D. A.; Abo Ali, E. A.; Othman, A. A.; Salah, W. \& El-Ebiary, A. A. (2015): Water pollution in the Middle Nile Delta, Egypt: An environmental study. J. .Adv. Res.; 7: 781-794.

El-Serag, H. B.; Marrero, J. A.; Rudolph, L. \& Reddy, K. R. (2008): Diagnosis and treatment of hepatocellular carcinoma. Gastroenterology; 134:1752-1763.

Feldmeier, H. \& Zwingenberge, K. (1988): Immunodignostik der Bilharziose: Ärzt lab, 34:287-292.

Gasim, G. I.; Bella, A. \& Adam, I. (2015): Schistosomiasis , hepatitis B, hepatitis C co-infection: Virology J.; 12(19): 1-6.

Gerencer, M.; Burek, V.; Crowe, B. A.; Barrett, N. P. \& Dorner, F. (1998): The role of complement and gp120-specific antibodies in virus lysis and CD4+ $\mathrm{T}$ cell depletion in HIV-1-infected patients. Microb.Pathog.; 25: 253-266.

Hui, A. Y.; Chan, H. L.; Wong, V. W.; Liew, C.; Chim, A. M.; Chan, F. K. \& Sung, J. J. (2005): Identification of chronic hepatitis B patients without significant liver fibrosis by a simple noninvasive predictive model. Am. J. Gastroenterol. ;100: 616-623.

Iacobellis, A.; Mangia, A.; Leandro, G.; Clemente, R.; Festa, V.; Attino, V. \& Ricciard, R. (2005): External validation of biochemical indices for noninvasive evaluation of liver fibrosis in $\mathrm{HCV}$ chronic hepatitis. Am. J. Gastroenterol ;100: 868-873. 
Leckie, P.; Davies, N. \& Jalan, R. (2012): Albumin regeneration for extracorporeal liver support using prometheus: a step in the right direction. Gastroenterology; 142: 690-692.

Leite, L. A. C.; Filho, A. A. P.; da Fonseca, C. S. M.; dos Santos, B. S.; Ferreira, R. C. S.; Montenegro, S. M. L.; Lopes, E. P.; Domingues, A. L. C; Owen, J. S. \& Lima, V. L. M. (2013): Hemostatic Dysfunction Is Increased in Patients with HepatosplenicSchistosomiasisMansoni and Advanced Periportal Fibrosis. PLOS. Negl. Trop. Dis.; 7(7): e2314 doi:10.1371/journal.pntd.0002314.

Li, D.; Mallory, T. \& Satomura, S. (2001): AFP,-L3: a new generation of tumor marker for hepatocellular carcinoma. Clin.Chim.Acta. ;313(1-2):15-19.

Li,B. Li,B.,Guo,T. ,Sun,Z, . Li,X.,Li,X, .Wang,H, . Chen,W., Chen, P \& Mao,Y.(2017): The Clinical Values of Serum Markers in the Early Prediction of Hepatocellular Carcinoma; BioMed. Research International; (2017): Article ID 5358615.Locarnini, S.A.,(1998):Hepatiti B surface antigen and polymerase gene variants: Potential virological and clinical significance, Hepatology; 27(1):294-297.

Ni, H.; Soe, H. H. K. \& Htet, A. (2012): Determinants of abnormal liver function tests in diabetes patients in Myanmar. Int. Jr. Diabetes Res.; 1(3):36-41.

Noreldin, A. K. A.; Mohamed, A. S. \& Abdel Aziz, A. H. \& Ali, G. A. M. (2015): Correlation between liver function tests and polymerase chain reaction in chronic hepatitis C patients. J. Hepato. Gastroint. Dis .;1:1-11.

Pasha, M. K.; Reddy, M.G.; Kumar, B. R.; Srinivasulu, M.; Suseela, K.; Ayesha, Q.; Sharma, G. \& Alex, L. (2017): Immunoglobulin and complement levels in liver cirrhosis and ovarian cancer ascites patients. W.J. Pharmaceutical and Med. Res.;3(3): 169-173.

Qin, X. \& Gao, B. (2006): The complement system in liver diseases. Cellular \& molecular Immunology.;3(5): (333-340). 
Ruane, P.; Ain, D.; Stryker, R.; Meshrekey, R.; Soliman, M; Peter, R.; Riad, W. J.; Mikhail, S.; Kersey, K.; Jiang, D.; Massetto, B.; Doehle, B.; Kirby, B. J.; Knox, S. J., McHutchison, G. J. \& Symonds, W. T. (2015): Sofosbuvir plus ribavirin for the treatment of chronic genotype 4 Hepatitis $\mathrm{C}$ virus infection in patients of Egyptian ancestry: J. Hepatol.;62(5): 1040-1046.

Souza, M. R.; Toledo, C. F. \& Borges, D. R. (2000): Thrombocytemia as a predictor of portal hypertension in schistosomiasis. Dig. Dis. Sci.; 45:1964-1970.

Speth, C.; Stobier, H. \& Dierich, M.P. (2003): Complement in different stages of HIV infection and pathogenesis. Int. Arch. Allergy Immunol.; 130(4):247-257.

Thomas, L. (1998): The complement system .In: Thomas L. \& ediators. Clinical laboratory diagnostics. Frank frut: Th.-books verlagsgesllschaft; 811-821.

Tarr, A. W.; Richard, A.; Urbanowicz, R. A. \& Ball, J. K. (2012): The role of humoral innate immunity in hepatitis Cvirus infection. Viruses; 4: $1-27$.

Terajima, M.; Cruz, J.; Co, M. D.; Lee, J. H.; Kaur, K.; Wilson, P. C. \& Ennis, F. A. (2011): Complement dependent lysis of influenza A virus infected cells by broadly cross-reactive human monoclonal antibodies. J. Virol.; 85: 13463-13467.

Toda, KS.; Kikuchi, L.; Chagas, A. L.; Tanigawa, R. Y.; Paranaguá-Vezozzo, D. C.; Pfiffer, T.; Rocha, M. .D., Alves, V. A. F. \& Carrilho, F. J. (2015): Hepatocellular Carcinoma Related to Schistosomamansoni Infection: Case Series and Literature Review. J. of Clin.and Translational Hepatol.; 3 :260-264.

Vogel, M.; Deterding, K.; Wiegand, J.; Gruner, N. H.; Baumgarten, A.; Jung, M. C.; Manns, M. P.; Wedemeyer, H. \& Rockstroh, J. K. German Hepatitis Group \& Hep-Net. (2009):.Initial presentation of acute hepatitis $\mathrm{C}$ virus (HCV) infection among HIV-negative and HIVpositive individuals-experience from 2 large German networks on the study of acute HCV infection. Clin. Infect. Dis.; 49(2):317319. 
World Health Organization (WHO) (2015): Hepatitis C: fact sheet.number:164.Available/from:http://www.who.int/mediacentr e/factsheets/fs164 /en/rev.

World Health Organization (WHO) (2017): WHO schistosomiasis fact sheet.Avaliableat:http://www.who.int/mediacentre/factsheets/fs1: 5/en.update 2017.

Zakhary, N. I.; El- Merzabani, M. M.; El-Sawi, N. M.; Saleh, S. M.; Moneer, M. M. \& Mohammad, R. H. (2011): Impact of different biochemical markers in serum of patient with benign and malignant liver diseases.Journal of Advanced Research; 2(1):4955 .

Zhang, G.; Zhang, T.; Ye, Y.; Liu, J.; Zhang, X.; Xie, C.; Peng, L. \& Gao, Z. (2016): Complement factor 3 could be an independent risk factor for mortality in patients with HBV related acute on chronic liver failure .Journal of Biomed research international ;:1-10.

Zhou, L.; Liu, J. \& Luo, F. (2006): Serum tumor markers for detection of hepatocellular carcinoma. World J. Gastroenterol, 12:1175-1181. 


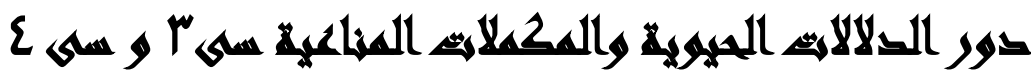

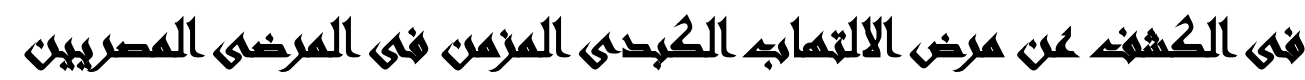

[1]

حنان محمد فتحى عبد الوهاب(')- أمل عشماوي احمد القرش(')-- محمد حسن إبراهيم(r)

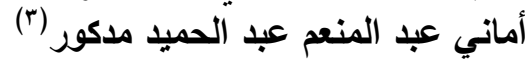

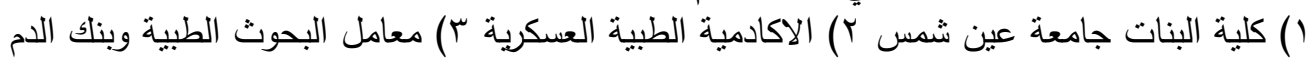

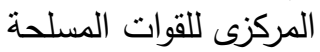

\section{المستخله}

نسبة كبيرة من المصريين بعانون من عبء كبير بسبب أمراض الكبد، ويرجع ذلك فى الغالب

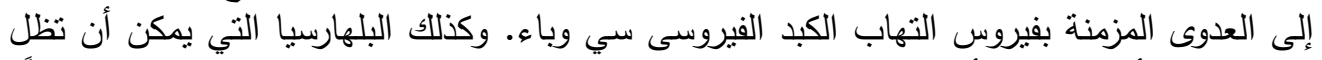

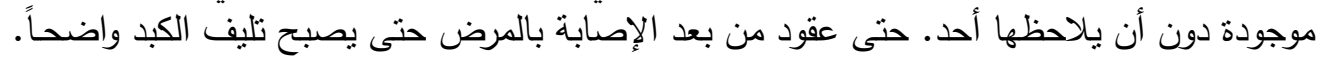
تتشمل هذذه الدراسة المرضى المصابين الذين يحضرون في مختبر الإنبر البحوث الطبية وبنك الدم

$$
\text { المركزي للقوات المسلحة. }
$$

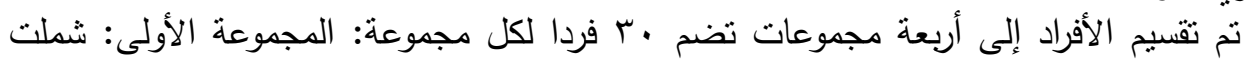

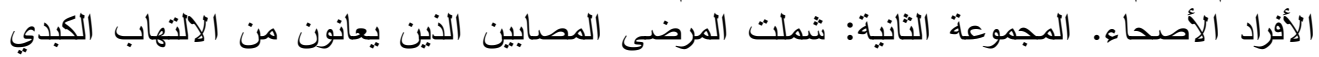

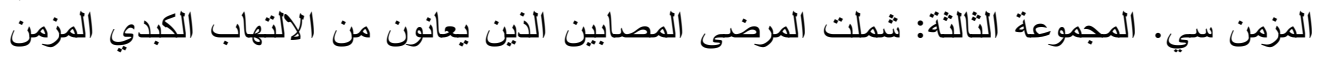

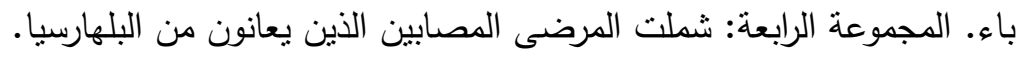

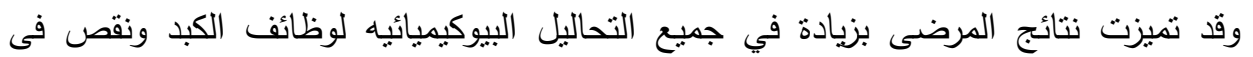

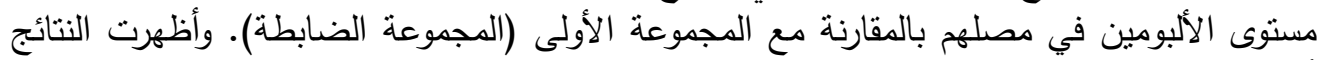

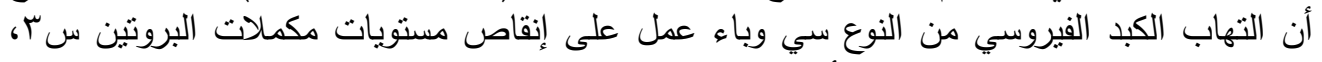

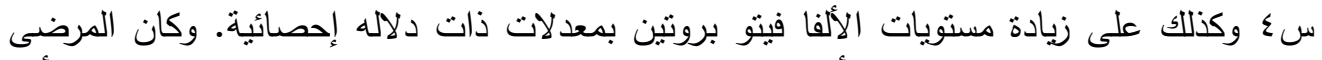

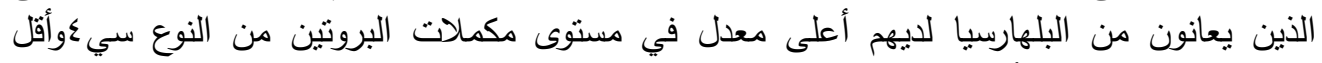

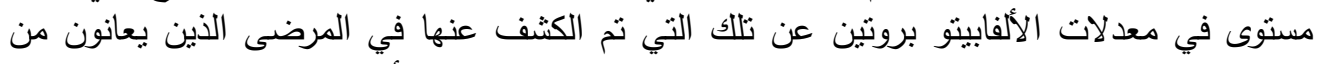

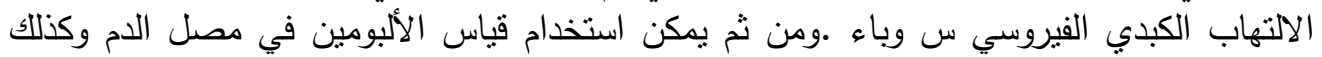

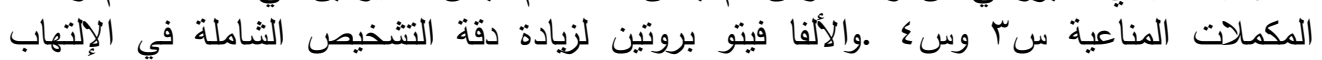

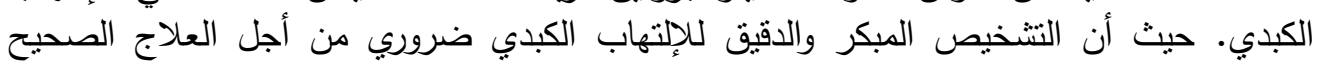
للمرضى. 